\title{
The Effect of Cobalt Ions on Amino Acid Sensors Using Parsley Seeds
}

\author{
Yuichi SATO*, Ayano KOTAKE ${ }^{\dagger}$ and Koichi KOBAYAKAWA
}

Received June 6, 1995 ; Accepted August 2, 1995

\begin{abstract}
A potentiometric ammonia gas sensing electrode immobilized by minced parsley seeds responds to amino acids such as L-asparagine and urea. Cobalt ions present in the solution decrease the sensitivity of the electrode. There seem to be four reasons for this, i.e., 1) the complex formation of cobalt ion with L-asparagine, 2) cobalt ammine complex ion formation, 3) the interference of the cobalt ion with the ammonia electrode, 4) catalytic acitivity decrease of the enzyme in parsley seeds due to cobalt ion, where the contribution of reason 1) does not seem to be large.
\end{abstract}

\section{INTRODUCTION}

Plant substances have been used as biocatalytic layers coupled with potentiometric or amperometric techniques ${ }^{1.2)}$. Their easy preparation and low cost are very attractive for the construction of biosensors. In previous papers, we presented an amino acid and urea sensor using minced parsley leaves ${ }^{3)}$ and minced parsley seeds $^{4 \nmid}$ with a potentiometric ammonia gas sensing electrode. This sensor responded to $\mathrm{L}$-asparagine, $\mathrm{L}-$ glutamine, L-serine and urea with a Nernstian slope of 43-51 $\mathrm{mV}$ per decade of substrate concentration with good time stability over 30 days. Its principle is that a substrate such as L-asparagine in the solution passes through the membrane, diffuses into the plant tissue and decomposes to ammonia and other substances due to the catalytic action of the enzyme contained in the parsley. The ammonia electrode then responds to the ammonia produced.

In the present paper, we studied the effect of cobalt ions on the biocatalytic activity of parsley seeds on the amino acid sensing ability. Because transition metal ions are expected to have a bad influence on the catalytic activity of the enzyme, it seems to be worth studying their effect.

Faculty of Engineering, Kanagawa University (Rokkakubashi, Kanagawa-ku, Yokohama, 221 Japan)

$\dagger$ Faculty of Science, Kanagawa University (Tsuchiya, Hiratsuka, 259 . 12 Japan)

Key Words : Amino Acids Sensor, Enzyme Sensor, Parsley Seeds, Cobalt Ion Effect

\section{EXPERIMENTAL}

An Orion model 95-10 ammonia gas electrode was used in the construction of the biosensors. Potentiometric measurements were carried out using a Corning Model SA 720 ion meter. The parsley (Petroselinum crispum) seeds used were commercially available (Sakata Seeds Corp.). After soaking in $0.1 \mathrm{~mol} / \mathrm{dm}^{3}$ Tris- $\mathrm{HCl}$ buffer solution at $\mathrm{pH} 7.4$ for $24 \mathrm{~h}$, the seeds were minced using a razor blade or ground in an agate mortar with a pestle. Then 1-10 mg of minced seeds of parsley were attached to the surface of the ammonia electrode, covered with a dialysis membrane and fixed using an O-ring. The immobilized-seed electrode was dipped in $0.1 \mathrm{~mol} / \mathrm{dm}^{3}$ Tris- $\mathrm{HCl}$ buffer solution. To determine the response at this electrode, amino acids were added to the buffer solution, and the potential change due to $\mathrm{NH}_{3}$ liberated from the substrate by the catalytic reaction of the enzyme contained in parsley was followed. All chemicals used were of reagent grade (Wako Pure Chemical Industries Co.). Amino acid solutions were prepared fresh each day with deionized water $(18 \mathrm{M} \Omega \mathrm{cm})$. Cobalt nitrate was used as the cobalt ion source.

\section{RESULTS AND DISCUSSION}

In the absence of $\mathrm{Co}^{2+}$, the parsley seeds electrode responds very well to L-asparagine, whose Nernstian slope is $54 \mathrm{mV} /$ decade nearly equal to the theoretical value of $59.2 \mathrm{mV}$ (Fig. 1). The presence of $\mathrm{Co}^{2+}$, however, interfered with the response of the electrode. As the $\mathrm{Co}^{2+}$ concentration present in the solution inccreased, the electrode sensitivity decreased. Over some concentration level, the electrode did not respond 


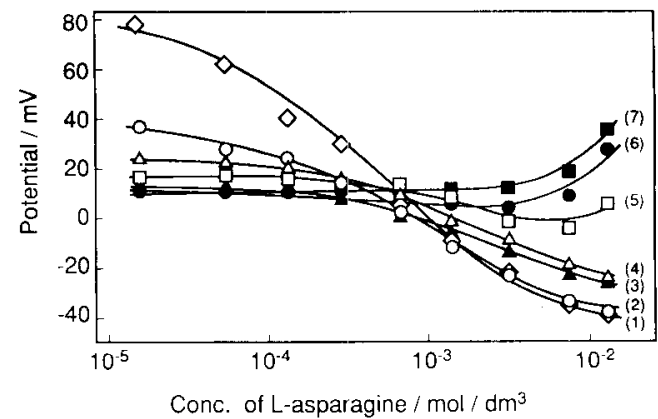

Fig. 1 Calibration curves for L-asparagine using an electrode with a layer of $6 \mathrm{mg}$ immobilized minced parsley seeds immersed in $0.1 \mathrm{~mol} / \mathrm{dm}^{3}$ Tris- $\mathrm{HCl}$ buffer and cobalt nitrate in $\mathrm{pH} 7.4,30^{\circ} \mathrm{C}$.

Concentration of $\mathrm{Co}^{2+}\left(\mathrm{m} \mathrm{mol} / \mathrm{dm}^{3}\right)=(1) 0,(2) 3,(3) 5$, , (4) 10 , (6) $15,(7) 20$

to L-asparagine (Fig. 1, curves 2-7).

There seem to be four reasons to explain this $\mathrm{Co}^{2+}$ ion effect.

1. The complex formation of $\mathrm{Co}^{2+}$ with $\mathrm{L}$-asparagine, which decreases the free $\mathrm{L}$-asparagine concentration.

2. The formation of cobalt-ammine complex ion, such as $\left[\mathrm{Co}\left(\mathrm{NH}_{3}\right)_{6}\right]^{2+}$. If such an ammine complex formation occurs, the concentration of free ammonium ions liberated from $\mathrm{L}$-asparagine decreases, i.e. the ammonia electrode does not respond.

3. The interference effect of cobalt ion on the ammonia electrode.

4. The decrease of the catalytic activity of the enzyme electrode due to cobalt ion.

Stability constants for $\mathrm{Co}^{2+}$ with L-asparagine are $\log K_{1}=4.51$ and $\log K_{2}=3.50$ respectively ${ }^{5)}$. Although the stability constant for $\mathrm{Co}^{2+}$ with urea seems to be unknown, its value is expected to be much smaller than that with L-asparagihne. According to the IrvingWilliams series, the stability constant for $\mathrm{Cu}^{2+}$ is larger than that with $\mathrm{Co}^{2+}$ for a nitrogen-containing ligand. So because the $\log$ of the stability constant for $\mathrm{Cu}^{2+}$ with urea is $0.7^{\text {6) }}$, that for $\mathrm{Co}^{2+}$ with urea seems to be smaller than this value. On the other hand, the cobalt ion effect on urea calibration curves showed almost the same degree of effect as that for L-asparagine. Urea responds to the parsley electrode with a slope of $47 \mathrm{mV} /$ decade in the absence of cobalt ion ${ }^{4)}$. From the above estimation, the stability constant for $\mathrm{Co}^{2+}$ with urea seems to be much smaller than that with L-asparagine. So, if the main cause is reason 1 , i.e., the complex formation of cobalt ion with L-asparagine, the effect of $\mathrm{Co}^{2+}$ upon the calibration curve for urea should be smaller compared to the case for L-asparagine. However, the cobalt icn effect upon the urea calibration curve is the same degree as that for L-asparagine. Consequently, reason 1 does not seem to be the main cause for cobalt ion interference and other causes may be involved. Figure 2 shows calibration curves for Lasparagine (curve 1) and for cobalt ion using the parsley seed electrode in $0.1 \mathrm{~mol} / \mathrm{dm}^{3}$ Tris- $\mathrm{HCl}$ buffer solution with various concentrations of $\mathrm{L}$-asparagine (curves 2 4). For curves 2,3 and 4, the potential increased as the cobalt ion concentration increased, especially from about $5 \times 10^{-3} \mathrm{~mol} / \mathrm{dm}^{3}$, which means that the concentration of $\mathrm{L}$-asparagine apparently decreased, i.e., the concentration of free ammonia decreased, which suggests that formation of complex ions such as $\left[\mathrm{Co}\left(\mathrm{NH}_{3}\right)_{\mathrm{x}}\right]^{2+}$ occurred (reason 2). The cobalt ion effect on an ammonia electrode in place of a parsley seedimmobilized electrode at various ammonium ion concentrations was also studied. The results are shown in Fig. 3. Although the potential values are different, curves 2,3, and 4 show almost the same behavior as those in Fig. 2, which suggests that the above interpretation is correct. The stability constant, $B_{f}$ for the hexaammine cobalt complex ion, $\left[\mathrm{Co}\left(\mathrm{NH}_{3}\right)_{6}\right]^{2+}$ is 5.14 , while that of the tetraammine copper ion $\left(B_{4}\right)$,

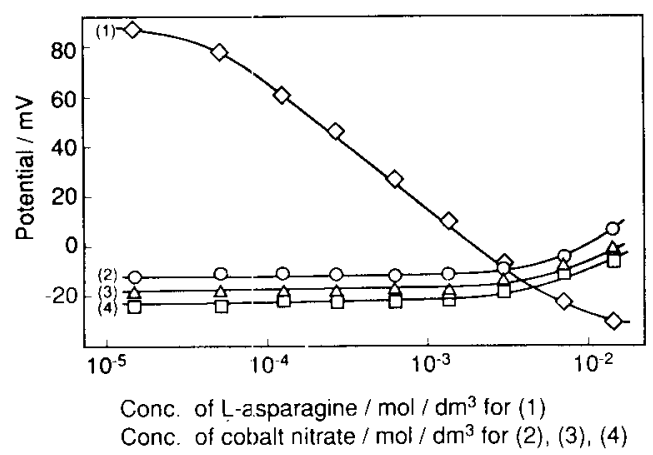

Fig. 2 Calibration curves for L-asparagine (1) and calibration curves for cobalt nitrate using an electrode with a layer of 6 mg of immobilized minced parsley seeds immersed in $0.1 \mathrm{~mol} /$ $\mathrm{dm}^{3}$ Tris- $\mathrm{HCl}$ buffer with various concentrations of $\mathrm{L}$ asparagine at $\mathrm{pH} 7.4,30^{\circ} \mathrm{C}$.

Concentration of L-asparagine $\left(\mathrm{m} \mathrm{mol}^{-} \mathrm{dm}^{3}\right)=(2) 3,(3) 5$, (4)7. 
$\left[\mathrm{Cu}\left(\mathrm{NH}_{3}\right)_{4}\right]^{2+}$ is $12.67^{7}$, i.e., copper ion is more likely to form an ammine complex ion than cobalt ion. If the cause of the potential increase at a higher concentration of cobalt ion in Figures 2 and 3 is due to the decrease in free ammonium ion in the solution by the complex formation, its degree will be more remarkable in the case of copper ion. This was confirmed as shown in Fig. 4, where the potential increases more remarkably compared to the cobalt ion case (Fig. 3) on increasing the copper ion concentration.

The plot (1) in Fig. 3 which was obtained in the solution containing no ammonium ion is not linear, and the ammonia electrode potential decreased when a higher concentration of cobalt ion was titrated. This means that cobalt ion interferes with the ammonia electrode. In the case of copper ion, however, the corresponding plot is linear and copper ion does not interfere with the ammonia electrode as shown in Fig.

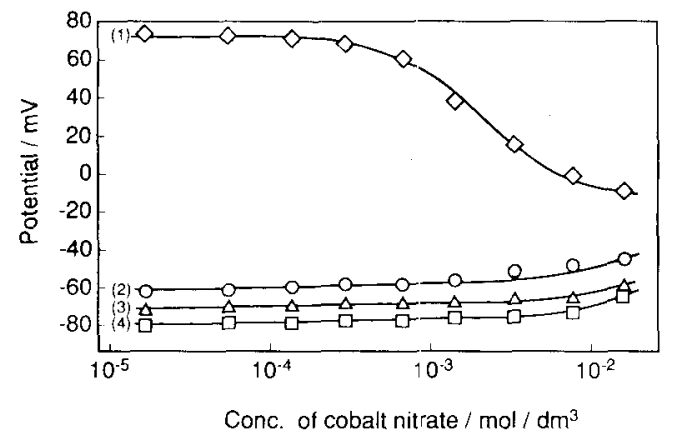

Fig. 3 Calibration curves for cobalt nitrate using an $\mathrm{NH}_{3}$ electrode in $0.1 \mathrm{~mol} / \mathrm{dm}^{3}$ Tris- $\mathrm{HCl}$ buffer and $\mathrm{NH}_{4} \mathrm{Cl}$ at $\mathrm{pH}$ $7.4,30^{\circ} \mathrm{C}$.

Concentration of $\mathrm{NH}_{4} \mathrm{Cl}\left(\mathrm{m} \mathrm{mol} / \mathrm{dm}^{3}\right)=(1) 0,(2) 3,(3) 5,(4) 7$.

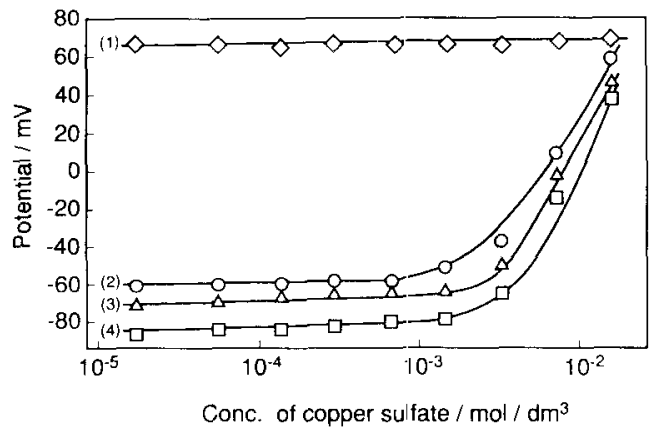

Fig. 4 Calibration curves for copper sulfate using an $\mathrm{NH}_{3}$ electrode in $0.1 \mathrm{~mol} / \mathrm{dm}^{3}$ Tris- $\mathrm{HCl}$ buffer and $\mathrm{NH}_{4} \mathrm{Cl}$ at $\mathrm{pH} 7.4,30^{\circ} \mathrm{C}$. Concentration of $\mathrm{NH}_{4} \mathrm{Cl}\left(\mathrm{m} \mathrm{mol} / \mathrm{dm}^{3}\right)=(1) 0,(2) 3$ (3) $5,(4) 7$.
4 (curve 1). Calibration curves for $\mathrm{NH}_{4} \mathrm{Cl}$ using an ammonia electrode in Tris- $\mathrm{HCl}$ buffer solution in the absence and the presence of various concentrations of cobalt ion were measured (Fig. 5). In the absence of cobalt ion, the ammonia electrode showed the normal behavior with a Nernstian slope of $58 \mathrm{mV}$. In the presence of cobalt ion in the solution, the ammonia electrode responded to cobalt ion, and the potential decreased from the initial titration point of ammonium ion. With increasing cobalt ion concentration, the slope decreased and the sensitivity to ammonium ion dropped. These results involved reason 3 .

Finally, the feasibility of the catalytic activity decrease due to cobalt ion (reason 4) was studied. Curve 2 in Fig. 6 was obtained after a cobalt ion effect test such as the experiment shown in Fig. 1. Clearly, the electrode activity decreased though the electrode was washed with deionized water after the cobalt ion effect

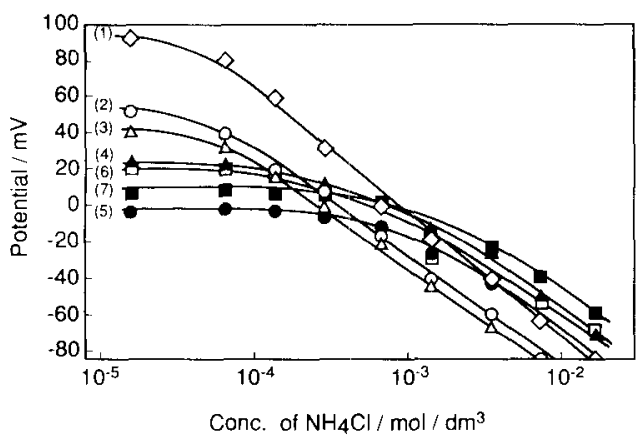

Fig. 5 Calibration curves for $\mathrm{NH}_{4} \mathrm{Cl}$ using an $\mathrm{NH}_{3}$ electrode in $0.1 \mathrm{~mol} / \mathrm{dm}^{3}$ Tris- $\mathrm{HCl}$ and cobalt nitrate at $\mathrm{pH} 7.4 .30^{\circ} \mathrm{C}$. Concentration of $\mathrm{Co}^{2+}\left(\mathrm{m} \mathrm{mol} / \mathrm{dm}^{3}\right)=(1) 0$, (2)3, (3)5, (4)7, (5) 10 , (6) $15,(7) 20$.

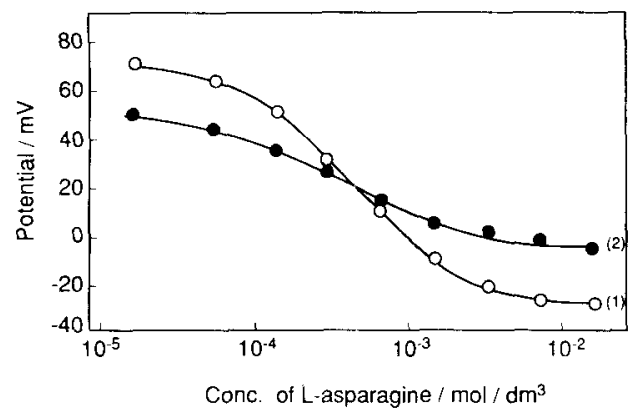

Fig. 6 Calibration curves for L-asparagine before (1) and after a $\mathrm{Co}^{2+}$ effect test (like that of Fig. 1) using an electrode with a layer of $6 \mathrm{mg}$ of immobilized minced parsley seeds immersed in $0.1 \mathrm{~mol} / \mathrm{dm}^{3}$ Tris- $\mathrm{HCl}$ buffer at $\mathrm{pH} 7.4,30^{\circ} \mathrm{C}$. 
test. Nearly the same shape of calibration curve for Lasparagine was obtained after using the electrode in a test like that of Fig. 2. This behavior suggests that cobalt ion decreases the catalytic activity of the enzyme electrode. From the above results and discussion, three or four reasons for the cobalt ion effect may be involved in the decrease of the amino acid sensing ability of the parsley seed electrode. They are interwined complicatedly and their degree of contribution can not be separated.

\section{CONCLUSION}

The sensing ability of a sensor for amino acids as L-asparagine using minced parsley seeds with a potentiometric ammonia gas sensing electrode decreases when cobalt ion is present in the solution. There seem to be four reasons which may be involved in this biocatalytic activity decrease, i.e., 1) the complex formation of cobalt ion with L-asparagine, 2) cobalt ammine complex formation, 3) the interference of cobalt ion with the ammonia electrode, 4) catalytic activity decrease of the enzyme duc to cobalt ion. Reason 1), i.e., the contribution of the effect of complex formation of L-asparagine with cobalt ion may not be very great.

\section{References}

1) G.A.Rechnitz, Scienie, 214, 287 (1981).

2) M.A.Arnold and G.A.Rechnitz, A.F.P.Turner, I.Karube and G.Wilson (Eds.), Biosensors, Fundamentals and Application, Oxford University Press, p.30 (1988).

3) Y.Sato, K.Chikyu and K.Kobayakawa, Chem. Lett., 1989, 1305.

4) Y.Sato, T.Makino and K.Kobayakawa, Bioelectrochem Bioenergetics., 27, 199 (1992).

5) Stability Constants of Metal-Ion Complexes, Supplement No.1, Special Publication No.25, ed. L.G.Sillen and A.E.Martell, The Chemical Society, Burlington (London), p. 343 (1971)

6) Stability Constants of Metal-Ion Complexes, Supplement No.1, Special Publication No.25, ed. L.G.Sillen and A.E.Martell, The Chemical Society, Burlington (London)., p. $738(1971)$.

7) Stability Constants of Metal-Ion Complexes, Supplement No.1, Special Publication No.25, ed. L.G.Sillen and A.E.Martell, The Chemical Society, Burlington (London)., p. 84 (1971). 